\title{
New Mechanisms for Recovering Budgetary Claims in Insolvency
}

\author{
By Lavinia-Olivia Iancu
}

\begin{abstract}
The Emergency Ordinance No. 88/2018, on the amendment and supplement of several regulatory documents in the field of insolvency, was adopted in accordance with the objectives of the 2018-2202 Romanian Government program, which targets economic growth, the improvement of the business environment and the increase of the budgetary income collection level. Certainly, streamlining the insolvency procedures while consequently improving and protecting the creditors' rights should contribute substantially to the improvement of the business climate, creating the conditions for the rectification of viable businesses and a faster recovery of claims. However, an analysis of the amendments brought to the Insolvency Law leads to the conclusion that they do not target the creditors' protection in general, but focus strictly on the budgetary creditors. Although the idea of increasing the amounts collected to the state budget from insolvent companies is a coherent idea of any government, it often contradicts the principles that govern insolvency in Romania, rendering its practical implementation difficult, or even impossible.
\end{abstract}

Keywords: Insolvency; Budgetary claims; Principles.

\section{Introduction}

At the end of 2018, the Romanian Government determined ${ }^{1}$ that the insolvency regulations, Law No. $85 / 2014^{2}$, must be amended, as the recovery process of tax receivables from insolvent companies had to be streamlined in observance with one of the main aims of the insolvency process, that insolvent businesses have the opportunity to rectify themselves and recover.

The legislative amendment was intended to be implemented at the same time as the realisation of Romania's Governing Program for the 2018-2020, which included plans for economic growth and the improvement of the business environment, but also the increase of the tax receivables collection level. Within this context, by means of the Emergency Ordinance No. 88/2018 a series of amendments were brought to the insolvency regulations. Two of these amendments were considered to have a major impact, affecting the very principles of the insolvency procedure.

\footnotetext{
*Dr. of Law, Lecturer, Faculty of Economics, Tibiscus University of Timişoara, Romania. Email: relicons@yahoo.com.

${ }^{1}$ The substantiation note of the Government Emergency Ordinance (OUG) No. 88/2018 can be found on the Romanian Government website: http://gov.ro/ro/guvernul/procesul-legislativ/no te-de-fundamentare/nota-de-fundamentare-oug-nr-88-27-09-2018\&page $=14$

${ }^{2}$ Law no. 85/2014 for the Procedures of Preventing Insolvency is also known as the New Code of Insolvency. ${ }^{2}$
} 
With the justification of the desideratum to expand the tax receivables collection level within the insolvency procedure, the legal framework was created in order to activate the forced execution of the insolvency procedure and compel the debtor to submit an insolvency procedure initiation request when the tax receivables exceed $50 \%$ of the total value of the receivables. However, reinforcing the position of the budgetary creditor in the insolvency procedure, so as to require the debtors to respect the payments assumed for the budgetary claims, cannot lead to an unfair treatment of the other categories of creditors and must not violate the very established principles of the Insolvency Law.

\section{Insolvency Law in Romania}

The New Code of Insolvency establishes in Article 4 the fundamental principles guiding and regulating the entire procedure. The following principles are most relevant to the proposed analysis:

- Maximising the rate of asset selling and receivable recovery.

- Providing the debtors the opportunity to efficiently and effectively redress the business.

- Providing equal treatment of creditors with similar ranking.

- Acknowledging the existing rights of creditors and observing the priority order of receivables, based on a set of clearly determined and uniformly applicable rules.

The judicial doctrine ${ }^{3}$ was constant in outlining the features of the insolvency procedure: a judicial, collective, uniform and general procedure.

In recent years, the insolvency regulations have become a priority for the Romanian lawmaker, who constantly observed the correlation of the legal provisions with the economic reality in order to support the business environment. Naturally, the protection of the insolvent debtors is correlated with the protection of their creditor's rights.

Within the insolvency procedure, it is important to balance between the debtor's rights and the rights of their creditors. On the one hand, the legal regulation must allow the debtor to access the procedure with the first signs of financial imbalance and protect him for a certain period, within which he will have the opportunity to reorganise his business and pay both unsettled and current debts. From the standpoint of the creditor, who has to recover money within the insolvency procedure, this regulation allows the debtor's reorganisation only if the creditor's rights are protected. The very principles of the insolvency procedure guarantee equal treatment of creditors with similar ranking, acknowledge the creditors' rights and ensure the receivables' payment priority order based on clear rules.

\section{Intervention}

\footnotetext{
${ }^{3}$ Bufan (2001) at 49-52; Deli-Diaconescu (2019) at 69.
} 
Debtor's Interdiction to submit the Insolvency Procedure Initiation Request when the Tax Receivables Exceed 50\% of the Value of Receivables

Access to the insolvency procedure is available to any debtor in financial difficulty, whose debts are older than 60 days and amounting to no less than 40,000 Romanian Lei (approximately 8,700 euro).

Insolvency is defined as the asset state characterised by the insufficiency of available funds for the payment of certain, liquid and exigible debts. ${ }^{4}$ The debtor's insolvency is presumed when, after 60 days from the due date, the debtor has not paid his debt to the creditor. Insolvency is imminent when it is proven that the debtor will not pay the debts that he has accrued with the available funds on the due date. The threshold value ${ }^{5}$ is the minimum amount of the receivables required so as to submit the insolvency procedure initiation request, 40,000 Romanian Lei, both for the creditor and for the debtor.

Article 1 para. 1 of Emergency Ordinance 88/2018 integrates the conditions that a debtor must fulfil when intending to submit the insolvency initiation request as follows: when the insolvency procedure initiation request is submitted by the debtor, the tax receivable quantum must be lower than $50 \%$ of the stated total of debtor's receivables.

This additional requirement, instituted as a mandatory condition for the debtor undergoing financial difficulties, contradicts the very purpose for which the insolvency law was amended, and the principles that guide the insolvency law.

Article 2 of Law No. 85/2014 clearly states the purpose of the insolvency procedure, i.e. instituting a collective insolvency procedure to cover the debtor's liabilities by providing, when possible, a chance for the redressal of his activity. The creation of a legal framework favourable to the reorganisation of a business going through difficulties has been a desideratum of the Romanian lawmaker since the adoption of Law No. 85/2014, when a series of legal amendments were made in order to encourage the debtor to get early access to the insolvency procedure and encourage a successful reorganisation. The amendment, brought by OUG 88/ 2018, seems to oppose this concept, favouring the tax creditor in an impermissible fashion.

According to the amendment, if a debtor's tax receivables exceed $50 \%$ of the total debts towards the tax creditor, the former will be prohibited from initiating the insolvency procedure and may be subject to forced execution. It is important to note that one of the main effects of initiating the insolvency procedure is the "automatic stay" granted to debtors, i.e. the rightful suspension of all judicial, extrajudicial actions or forced execution measures implemented in order to collect the receivables against the debtor's assets. Thus, it becomes obvious that in the absence of an "automatic stay" effect - specific to the insolvency procedure, the tax creditor's way to forced executions is open.

To stress the importance that the Romanian lawmaker granted in 2014 to the early reorganisation concept, note the provisions of Article 66 para. 11 of Law No. 85/2014, which give the syndic judge the option to waive, in emergency cases,

\footnotetext{
${ }^{4}$ Article 5 para. 29 of Law No. 85/2014.

${ }^{5}$ Ibid.
} 
the temporary suspension of any procedure of forced execution of the debtor's assets before the settlement of the insolvency procedure initiation request. Thus, the debtor's protection from forced execution disappears in accordance with the current regulation if the debtor's receivables are greater than $50 \%$ of the total receivables towards the tax creditor.

Romanian law is not alone in this approach. European ${ }^{6}$ and other international ${ }^{7}$ judicial systems tend to facilitate the debtor's early access to the insolvency procedure, in a preventative manner, at the first signs of financial difficulty, when the business may be saved by reorganisation. All the international reference documents, such as the UNCITRAL Guide and the European Insolvency Regulation, promote the equal treatment of creditors with similar ranking and the prevention of the institution of exceptions for certain types of creditors, as the insolvency procedure is a collective one and the creditors must have the same judicial treatment.

This concept is particularly fundamental given that the debtor is perceived as a commercial partner, provider, services user, client, employer and tax payer, and his failure will have a negative impact on all the people and businesses he is interconnected with through his business.

In conclusion, it seems that the described amendment has a major negative impact, representing a step backwards on the path to modernisation of the insolvency law in Romania. In addition, it constitutes a treatment that favours the tax creditor in an unfair fashion, as compared to the other creditors participating in the insolvency procedure.

\section{Starting Forced Execution for the Collection of Current Tax Receivables}

The lawmaker created a special judicial procedure for receivables created during the insolvency procedure, also known as "current receivables": nonpayment thereof gives the creditor the right to demand the initiation of the bankruptcy procedure against the debtor.

Article 75 para. 4 of Law No. 85/2014 determines that the holder of a current, certain, liquid and exigible receivable that was recognised by the official receiver or in relation to which the latter omitted to issue a decision within 10 days from the submission of the payment request or recognised by the syndic judge, in cases where the receivable amount exceeds the threshold value, may request, during reorganisation period, the initiation of the debtor's bankruptcy procedure. This is relevant only in cases where such receivables are not paid within 60 days from the date on which the official receiver takes the measure of admission or omits to issue a decision on the payment request or of the law court decision.

\footnotetext{
${ }^{6}$ The UNCITRAL legislative Guide on the insolvency law issued in 2004

${ }^{7}$ The 848/2015 Regulation of the European Parliament and of the Council on the insolvency procedures; Proposal of Directive of the European Parliament and of the Council on the preventive restructuring frameworks, second chance and measures to increase the efficiency of restructuring, insolvency and discharge procedures and to amend Directive 2012/30/UES, Strasbourg, 22.11.2016.
} 
In addition, the amendment brought by OUG 88/2018 to Article 143 of Law No. 85/2014 states that forced execution may be initiated for debts accumulated within the insolvency procedure period, which are older than 60 days.

Thus, although the insolvency law had a sanction in place for debtors who accumulated current receivables within the procedure by not respecting the payment due dates, allowing the debtor to submit the bankruptcy request, the option of forced execution was added to the law.

This is not the first time that the Romanian legislation has attempted to introduce forced execution for current receivables. A similar amendment was the object of OUG 92/2013, yet its noncompliance with the constitution was acknowledged by Decision No. 447/2013 of the Constitutional Court of Romania.

In its report ${ }^{8}$ on the insolvency law in Romania, the World Bank stated that the elimination of the text of OUG 91/2013 is commendable; no exceptions may be allowed to enable some creditors to initiate the forced execution procedure, as such exceptions tend to reduce the debtor's reorganisation chances, violate the rights of other creditors participating in the insolvency procedure, and, most of all, violate the fundamental principle of insolvency - collectiveness and equitableness.

The conclusions of the World Bank are in full agreement with the Principles for an Efficient Insolvency promulgated by the World Bank in 2015, which in principle $\mathrm{C} 5.2$ establishes that once the insolvency procedure has been initiated, it is prohibited to dispose of the debtor's assets and all the actions taken by creditors in order to realise their rights on the debtors' assets must be suspended.

At present, Romania does have insolvency procedures where a significant amount of current receivables are not paid by the debtor, by increasing the amounts of money to be paid to the creditors in bankruptcy. However, the possibility of activating individual forced execution, as it is regulated at present, is incompatible with the insolvency procedure.

The insolvency procedure is a procedure of collective forced execution, ensuring that no creditor is allowed to act individually to recover receivables. As already shown, the main effect of the initiation of the insolvency procedure is an automatic stay, i.e. the interdiction for any creditor to enforce the receivable against the debtor's assets. Two of the fundamental features of the insolvency procedure, equal treatment and the collective nature of the insolvency procedure, are violated when certain creditors are allowed to carry out forced executions.

Allowing chaotic forced executions of the debtor's assets for the purpose of collecting current receivables may profoundly affect any of the debtor's attempts to reorganise the business or sell it. Thus it can cause a situation where creditors in the reorganisation procedure or the current creditors who do not hold an enforceable title will force the initiation of the bankruptcy procedure so as to prevent a current creditor the opportunity to initiate a forced execution and reduce or deplete the debtor's assets, which would considerably reduce the chances of recovering the receivables.

\footnotetext{
${ }^{8}$ Report on the observance of the standards and the codes of judicial regime of insolvency and of the creditors/debtors' rights, World Bank, April 2014 available on the World Bank website: https://www.worldbank.org/content/dam/Worldbank/document/eca/romania/rosc/Romania\%20 ICR\%20ROSC\%20Final-April\%202014\%20COMPLET_clean_ro.pdf
} 
On the other hand, we may not ignore any possible fraudulent attempts by the debtor to extract certain assets from the insolvency procedure at modest prices specific to forced execution, by making fraudulent agreements with their current creditors.

In other words, the current situation can and does result in a conflict between the collective insolvency procedure - insolvency based on clear rules and derogatory from the general jurisdiction - and individual insolvency procedures, which exist according to the general jurisdiction rules.

There does not seem to be any solution for the concrete fashion in which the judicial or tax executor must proceed, given that he is compelled to notify the creditors who benefit from bases of priority, whereas they suspended the right to forced execution as per Article 75 para. 1 of Law No. 85/2014. In the event that the judicial executor ignores such an imperative provision and allows the creditors involved in the insolvency procedure to participate in the forced execution as per the general jurisdiction, a new problem will arise regarding the distribution of the money obtained. The Insolvency Law, the Civil Procedure Code and the Tax Procedure Code contain different rules for the distribution of monies obtained from selling the debtor's assets. By further following the analysed hypothesis, we may presume that the execution will be challenged, an action which will not fall within the competence of the syndic judge, but will be settled before the tax litigation court or the court of general jurisdiction. Such courts will most probably not be aware of the insolvency procedure, the amounts of money collected by the creditors within the procedure and the list of creditors. All these elements are capable of deeply affecting the fragile balance that must be provided between the protection of the debtor's rights and the protection of the creditors' rights.

Forced execution does not only mean pursuing or selling assets that belong to the debtor, but also pursuing the amounts of money due to the debtor. The management of access and operation of the insolvency account is clearly regulated by the Insolvency Law, meaning that even if the debtor's administration right is not withdrawn, any payment requires the approval of the insolvency practitioner; if the debtor's administration right is withdrawn, all the payments shall be made solely by the insolvency practitioner. According to the provisions of Article 163 para. 3 of Law No. 85/2014, it is strictly prohibited to freeze the insolvency account: "the insolvency account may not be frozen by any criminal, civil or administrative measure disposed by the criminal investigation bodies, by the administrative bodies or by the courts of law."

Despite this, in such cases two contradictory measures may exist - on the one hand, it is possible to force the execution of the debtor's income for failure to pay current receivables by garnishment of the account, while, on the other hand, it is prohibited to freeze the insolvency account.

As long as the automatic stay principle is violated by establishing exceptions for a certain category of creditors, the insolvency foundation is affected in its inner elements, its mechanisms thus becoming completely non-functional. ${ }^{9}$

\section{Practice "Corrects" the Legal Text}

\footnotetext{
${ }^{9}$ Miloș \& Deli-Diaconescu (2018) at 8.
} 
As far as the initiation of the insolvency procedure is concerned, some accountants have found a way to circumvent the limitations put in place when the tax receivables exceed $50 \%$ of the total debts: the debtor who intends to open the insolvency procedure is instructed to submit an intentionally erroneous debt statement to the tax authority and request the initiation of the insolvency procedure based on these accounting documents. Once the insolvency procedure initiation decision has become final, the debtor will submit amended statements to the tax authority.

It is particularly difficult to check whether this device to avoid the legal restrictions has been put into practice. At present, there is no documentation indicating that decisions to open the insolvency procedure were cancelled based on the fact that the submitted accounting documents were falsified for the sole purpose of initiating the insolvency procedure.

Forced executions are a different matter. The tax creditor has already initiated these procedures by issuing enforceable titles, demands for payment and institutions of garnishments on the accounts opened within the insolvency procedure. In response, several legal alternatives have been attempted, all with the purpose of blocking the individual forced execution. Thus, it is possible to find in the recent jurisprudence challenges of the execution procedure, requests for annulment, requests for presiding judge orders and requests for suspension of the forced execution.

Although the existing practice in the matter of individual forced execution pursuant to Article 143 of Law 85/2014 has been relatively low as of the current date, jurisprudential opinions have already crystallised:

1. Forced execution may only be applied to procedures opened under Law No. 85/2014, not to procedures opened under Law No. 85/2006.

The Insolvency Law No. 85/2014 was published in the Official Journal of Romania No. 466 of June 25th 2018. At the same time, Law No. 85/2006 on the insolvency procedure was also abrogated, yet insolvency procedures initiated before this date are still subject to Law No. 85/2006. ${ }^{10}$ Thus, even at present the Romanian law courts have on their dockets insolvency procedures governed by Law 85/2006, while those opened before June 24, 2014 are governed by Law No. $85 / 2014$.

Some tax creditors initiated forced executions against the debtors who owed them current receivables without taking into account which Law, No. 85/2006 or Law No. 85/2014, applied to them. Decision No. 242/01.02.2019 of Pascani Court, for example, established that: "forced execution indicated in Article 143 para. 1 of Law No. 05/2014, as amended by OUG 88/2018, is only allowed in the insolvency proceedings initiated after October 2, 2018 according to Law No. 85/2014, and not according to Law No. 85/2006." A Civil Sentence No. 415/13.05.2019 of the Salaj Court established that: "The reference by the tax creditor to the provisions of OUG No. 88/2018 may not be received in this case because it amends Law No. 85/2014 and not the old law No. 85/2006, so that the

\footnotetext{
${ }^{10}$ Article 343 of Law No. 85/2014.
} 
legislative amendments that allow the tax creditor to initiate the forced execution actions for current tax receivables at the same time as the collective procedure are not applicable in the cases which are judged according to the old law of insolvency and may not be opposed so as to antagonise the suspension of the forced execution measures provided by the law."

To the same end, Civil Sentence No. 2711/27.02.2019 of the Timisoara Court, determined that: "the insolvency procedure against the debtor claimant was opened according to Law No. 85/2006, which does not have similar provisions as the new Law of insolvency No. 85/2014. Since according to Article 343 of Law No. $85 / 2014$ the lawsuits were initiated before this law entered into force they remain subject to the law applicable before such date, therefore the legal provisions invoked in the statement of defence are not applicable to the case"

The syndic judge at the Civil Sentence No. 945/19.12.2018 of the Sebes Court considered that "the Insolvency procedure was initiated in relation to the claimant in accordance with Law No. 85/2006, therefore the provisions of Article $36^{11}$ are applicable, consequently the forced execution initiated by the respondent is subsequent to the initiation of the insolvency procedure against the debtor and has the same purpose as any other actions or measures of forced execution, and respectively it will be suspended as of right, as a natural consequence of the initiation of the insolvency procedure against the debtor."

Thus, a first important aspect clarified by the courts of law is that individual forced execution may not be initiated by the current creditors against debtors against whom the insolvency procedure regulated by Law No. 85/2006 was initiated, but only against debtors to whom Law No. 85/2014 applies, i.e. debtors in relation to whom the insolvency procedure was initiated before June 25, 2014.

2. Forced execution applies only to the insolvency procedures opened starting on 2 nd October 2018 and which are in the reorganisation stage

While forced execution may not be initiated against debtors to whom Law No. 85/2006 applies, in practice it is unclear whether all the debtors in relation to whom the initiation of the insolvency procedure was disposed according to Law $85 / 2014$ may be subjected to such measures. In order to examine this matter, following are a number of examples where OUG 88/2018 was applied to procedures initiated after its entry into force, October 2nd 2018, or OUG 88/2018 was applied to all the procedures initiated according to Law No. 85/2014.

In sentence No. 71/11.03.2019, the Dambovita Court established that: "the extension of the application of Article 143 of Law No. 85/2014 to the lawsuits initiated before OUG 88/2018 was entered into force is not permitted. Article 143 para. 1 of OUG 88/2018 finds its reason only in the case of lawsuits initiated before OUG 88/2018 was entered into force, while an exception from the rule of non-retroactive application of the law must be strictly specified, interpreted and applied."

\footnotetext{
${ }^{11}$ Article 36 of Law No. 85/2006 states that starting from the date of initiation of the procedure, all judicial, extrajudicial actions or forced execution measures are suspended as of right for the collection of the receivables from the debtor or his assets
} 
The Medias Court, in Conclusion No. 607/18.04.2019, reached a similar conclusion: "As far as the fashion of recovery by the creditors of the debts accumulated after the initiation of the insolvency procedure, the court acknowledges that the general principle of non-retroactive application of the civil law applies, as stated in Article 6 of the Romanian Civil Code, while the new provisions will apply to the procedures initiated after the date of entry into force of the amending law, October 2, 2018. The claimant entered insolvency in accordance with Law No, 85.2014, a normative act containing a set of regulations that guide the activity of the company subjected to the procedure, and therefore must be characterised by clarity and predictability and essential amendments may not be accepted, such as the one introduced in Article 143 of Law No. 85/2014, which denatures the collective meaning of the procedure in its entirety and changes the entire meaning of the procedure in existence when the claimant entered insolvency. Hence, the court acknowledges that in relation to the current receivables appearing against the claimant after entering insolvency, for the recovery thereof, the creditors do not have at their disposal the option of individual forced execution."

The Pascani Court considered in Decision No. 242/01.02.2019 that: "forced execution is only allowed in insolvency proceedings (calculated from the date of registration of the procedure initiation request) initiated as of October 2, 2018".

As may be concluded from the aforementioned examples, it seems that the new regulation, which allows individual forced execution, is significantly restricted in scope, and, more precisely, refers strictly to debtors whose insolvency was opened after October 2, 2018.

In the absence of a clear legal text, the jurisprudence intervention was required in order to establish the legal scope of application of individual forced execution in insolvency cases.

3. The requests referring to the forced executions initiated in accordance with Article 143 para. 1 of Law No. 85/2014 fall within the competence of the syndic judge

Once the law was in place, various requests were submitted for the annulment or suspension of forced execution measures to various courts: the general jurisdiction court when the Civil Procedure Code provisions were targeted, and the court specialising in administrative-tax litigation when the execution was carried out based on enforceable titles issued by the tax creditor or the court specialising in insolvency procedure.

In cases where the exception for lack of material jurisdiction of the syndic judge was invoked, decisions were handed down clarifying which court holds material jurisdiction so as to judge the actions based upon Article 143 para. 1 of Law No. 85/2014.

According to Civil Decision No. 42/R/23.01.2019 of the Court of Appeal of Brasov, "the rules established by the Civil Procedure Code on the jurisdiction of the execution court are not applicable considering the special character of the provisions of Law No. 85/2014." To the same end, Sentence No. 59/27.02.2019 of the Dambovita Court also stated that: "the acceptance of the material jurisdiction 
of resolution in favour of the execution court would lead to a severe impact on the collective and equitable nature of the insolvency procedure inasmuch as the protection granted to the debtor from the date of initiation of the insolvency procedure is also granted to all the creditors in competition, with respect to a possible bias or preferential treatment of one of them to the detriment of all the others."

In Sentence No. 145/14.05.2019, the Caras Severin Court also rejected the exception of lack of material jurisdiction of the syndic judge, although Article 714 and Article 615 of the Civil Procedure Code, referring to the appeal against the enforcement of execution, both establish that the district court as execution court has the jurisdiction to settle these type of cases. In the abovementioned matter, the forced execution was initiated by a tax creditor according to Article 143 para. 1 of Law No. 85/2014, representing the attempt of a creditor to individually recover the receivables after the date of initiation of the insolvency procedure of the debtor. Thus, the legality of the measures taken by this creditor from the standpoint of the Insolvency Law was unclear. Consequently, the jurisdiction of settlement belongs to the syndic judge.

\section{No garnishment may be imposed on the unique insolvency account}

Even though it is clear that OUG 88/2018 applies strictly to the insolvency procedures opened after October 2, 2018, it is still important to clarify how these forced executions will be carried out.

The simplest method of recovering current receivables for the tax creditor is the imposition of garnishment on the account. Yet any company in the insolvency procedure may carry out its collection and payment operations through a single account, entitled "the insolvency account", which is overseen by the insolvency practitioner, i.e. all the payments are made with his approval.

As already indicated, according to the provisions of Article 163 para. 3 of Law No. 85/2014, it is strictly prohibited to freeze the insolvency account: "the insolvency account may not be frozen by any criminal, civil or administrative measure disposed by the criminal investigation bodies, by the administrative bodies or by the courts of law." Nonetheless, the tax creditor may impose garnishments on the insolvency accounts of the debtors, while the courts may cancel such forced execution measures.

According to Decision No. 47/07.02.2019, the Commercial Court of Mures established that: "In the absence of a suspension of the measure of imposition of garnishment on the insolvency collection account, the debtor company may no longer make any payments, neither for current receivables resulting from current commercial relations occurring during the performance of the reorganisation plan confirmed by the creditors, nor for the receivables registered in the payment schedule of the confirmed reorganisation plan, which would create imminent damage both to the debtor company and to its creditors by the company failing to achieve its reorganisation plan and going bankrupt."

A much more elaborate justification, supporting the prohibition of freezing the insolvency account, can be found in the Civil Sentence No. 1/03.01.2019, 
pronounced by the Salaj Court: "The insolvency procedure is itself an executional procedure with strict applicability rules, so that the concrete fashion in which the forced execution of the tax creditor will be carried out must be detailed, given that the conditions under which the text of Article 163 para. 3 of Law No. 85/2014 were not amended, and it therefore completely prohibits any measure of freezing the debtor's insolvency account." From this point of view, it is impossible to approve a garnishment of the insolvent debtor's available funds and the current creditor has yet to activate other forms of forced execution other than the garnishment, such as the personal and real forced execution of the debtor's assets or the forced execution of third parties from which the debtor is to receive amounts of money. Even these latter modalities of forced execution must be carried out in accordance with the specific instructions of the insolvency procedure, under the conditions where the same assets or income may be assigned to bases of priority in favour of pre-existing creditors. Creditors registered to the list of creditors having previous receivables must comply with a de jure suspension on their right to request the forced execution on the insolvent debtor's assets.

Close scrutiny of the first wave of practice in the six months prior to the activation of OUG 88/2018, shows that the jurisprudence had a decisive role in diminishing the visibly negative effects of the legal provisions which allow the current creditor in the insolvency procedure to initiate the individual forced execution. Forced execution is allowed only with respect to the debtors who entered insolvency after November 2, 2018, and the legal control of the application of the forced execution measures falls within the material jurisdiction of the syndic judge who manages the insolvency procedure. In addition, the account containing the debtor's assets may not be garnished.

What, therefore, can the current creditor enforce from the insolvent debtor's assets? Without identifying the doctrine or the jurisprudence in the matter of personal (with the exception of garnishment) or real individual forced execution in insolvency, it seems that forced execution will only be permissible regarding the personal/real assets which do not have a basis of priority, are not necessary for the performance of the current activity of the debtor and are not essential for a successful reorganisation. If a tax creditor takes such aspects, which are not legislatively established, into account, in theory the creditor could carry out an individual forced execution for the recovery of current receivables. However, for such forced execution not to hinder the performance of the insolvency procedure, there must be a suitable collaboration between the insolvency practitioner and the judicial executor.

\section{Conclusion}

Before the amendment of the Insolvency Law by OUG 88/2018, the legal text granted a series of advantages to the budgetary creditor in general, but, above all, to the tax creditor. Thus, the tax creditor is informed about the insolvency procedure initiation request submitted by the debtor, as the proof of notification to the tax body with respect to the debtor's intention to enter insolvency is a 
mandatory document for the admissibility of the debtor's request. However, it is important to note that all the creditors have a time limit, established by the syndic judge, for the submission of the statements of receivables in relation to the debts preceding the initiation of the insolvency procedure. The tax creditor is exempt from this limit, and may submit by waiver a supplement of receivables following a tax inspection carried out within sixty days from the date upon which the Insolvency Procedures Bulletin published the notification referring to the initiation of the insolvency procedure.

Even if the aforementioned provisions, existing in the insolvency law, established a special system for the tax creditor, they were not received as an "unequitable treatment with respect to the other creditors participating in the insolvency procedure". This is because the large workload of such creditors was taken into account and, once informed of the debtor's intention to open the insolvency procedure, creditors were assigned a generous time limit for the performance of the tax inspection, as compared to the remaining creditors.

OUG 88/2018 is considered a step backwards in the matter of insolvency, as it prevents the debtors from accessing the procedure if a percentage greater than $50 \%$ of the total debts are budgetary, but, above all, allows the current creditor to initiate an individual forced execution within the framework of a collective forced execution.

The declared purpose of OUG 88/2018 may not be reached by provisions which, at a first glance, tend to determine an increase of the recoveries of budgetary receivables within the insolvency procedure. Yet, after a deep analysis, it is clear that these provisions affect the very concept of insolvency, by protecting the debtor going through financial difficulty and granting him a chance of redressal.

The simple introduction of a legal text allowing the activation of individual forced execution by the current creditor is of such that it confuses the collective insolvency procedure. If the lawmaker maintains its idea to allow individual forced executions within a collective procedure, it will have to regulate the concrete modality of performance thereof. As already indicated, the correction of an ambiguous and interpretable legal text was made by jurisprudence, but this is not the norm. The intention of jurisprudence to stop a "problematic" legal text from affecting the performance of an insolvency procedure is welcome, but this is not the role of law courts.

In my opinion, the introduction of an individual forced execution within a collective forced execution will raise difficulties which the lawmaker is not prepared to answer, while the responsibility for finding balance between the protection of the debtor's rights and the protection of the creditors' rights lies entirely with the court of law.

There are no solutions for this situation. If we accept that by introducing a single sentence into the legal text, stating that "for the debts accumulated within the insolvency procedure period which are older than 60 days, forced execution may be initiated", the principles promulgated in the matter of insolvency were violated, compromising the purpose of the insolvency procedure which grants the debtor a chance of reorganisation, the this sentence must be eliminated. If the 
lawmaker intends to allow the option of individual forced execution by the current creditors in the insolvency procedure, it must be regulated in detail, starting from the scope of application, material jurisdiction, measures of forced execution that may be taken, and categories of assets that may be subjected to forced execution. All these aspects that must be taken into account by the judicial executor, so as not to damage the adequate performance of the insolvency procedure.

The insolvency law in Romania was commended at a European level for its modernism and for the fact that it corresponded to the European principles that stress the reorganisation opportunity given to the debtor, "the second chance" and the equal and equitable treatment of the creditors within the insolvency procedure. The "3 rows of legal text" introduced by OUG 88/2018 have deprived it of this characterisation, and therefore an urgent intervention of the Romanian lawmaker is required.

\section{References}

Bufan, R. (2001). Reorganizarea judiciară și falimentul. București: Ed. Lumina Lex.

Deli-Diaconescu, A. (2019). Problema de compatibilitate dintre procedura insolvenței și Codul de procedură civilă. București: Ed. Universul Juridic.

Miloș, S.M. \& A. Deli-Diaconscu (2018). 'Analiza aspectelor de noutate aduse de OUG nr. 88/2018 la Codul insolvenței', in Revista de insolvență Phoenix nr. 66 octombriedecembrie 2018. București: Ed. Universul Juridic. 
